\title{
Students' Beliefs and Attitudes in Exploring Critical Literacy Comprehension towards Online Media Information into their Writing Practices
}

\author{
Rika Riwayatiningsih
}

Department of English Language Education, Universitas Nusantara PGRI Kediri, Indonesia

\begin{abstract}
Addressing critical literacy exploration into students' language learning is perpetuated in this digital media- dependent environment. Reading and writing competencies have also pertained the critical enactment in order to present the beyond textual values. Through class discussions and class observations among 12 tertiary English major students in a private university in Indonesia, this study explores students' beliefs and attitudes towards their critical literacy comprehension on online media information through writing practices. This exploratory case study collect the data covering the recordings of class discussions and class observations from student lesson implementation during their writing course. The results of this study reveal that most of the students are aware of the critical understanding of particular information conveyed from certain messages in their written works. Their beliefs on critical literacy agency has raised several attitudes of how they construct the social perspectives based on selections of what to include and exclude in their written texts. The article is also present recommendation to enlighten the learning in a critical stance.
\end{abstract}

Keywords: critical literacy, online media information, students' belief, writing practices.

\section{Introduction}

This paper arrised from the assertion that the central production of critical literacy in language classrooms lies in students writing. Since writing is the transmitting knowledge from the information after reading. This become the reason that reading plays a major role in writing. The interdependent between reading and writing make the construction of the literacy development. Research has found that when students read extensively, they become better writer. This belief is relevant with the concept that critical approach in reading and writing will make a difference to students' performance of writing production. The ways to understand and manipulate both the students' life experiences and the textual criticism led to the repertoire of critical literacy practices (Kamler, 2017). This notion can be asserted that working with writers'personal experiences- theoretically and pedagogically- will allow a critical engangement to the project of writing.

To be literate for today is changing as the new technologies have further contributed to the shifting of literacy definitions. Reading and writing skills suggest more on the ability to understand the word and the world. Freire's (1970) concept on literacy has exclusively influenced the learning goals of reading and writing skills. Teaching literacy includes how students learn and engage critically with the world around them after understanding the reading text (Vasquez et al., 2019). Through incorporating critical literacy practices in the classroom, teachers explicitly put students in the positions of power through the language construction (Freire \& Macedo, 1987; Janks, 2013). These learning experiences help students to critically aware that text is written from the authors' intention, and there is a

\footnotetext{
* Corresponding author.

E-mail address: rieka_72@yahoo.co.id (Rika Riwayatiningsih)
} 
silenced part that is not presented (Kamler, 2017). Subsequently, critical literacy presents students to question and examine what the messages of texts convey rather than easily accept the information.

The concept of critical literacy lied into several pedagogical moves. Comber (2014) described the social justice which underpin the critical literacy approach constructed from how students learn to research the language, explore the minority through language, and problematizing the general issues. Thereupon, Freire (2000) in his pedagogy of the opressed vividly offered the critical model in pedagogy lead to problem posing experience to see the world for transformation. As a concern, Iyer's (2010) research found that to ascertain the outcome of the critical literacy, teachers need to emerge the changing of pedagogy and learning with adequately contextulaised learning content. In other words, critical literacy will be in its utmost performance if teachers offer the classroom with activities that connect the texts that is useful for students' life. As Kamler (2017) pointed out that texts on students'live stories will make a difference for critical approach in language classroom.

The presentation of online media has shaped people in reading the information with a wide range of modalities, formats, and platforms. These experiences eventually acknowledge the skills in analyzing codes and conventions of texts media through cultivating abilities to interpret the multiple meanings and messages. As Fajardo (2015) argued that critical literacy practices help learners in coping with different relations of text in various views and voices concerning to power, gender, race, social, or powerlessness . The convention in which critical literacy practices entail is to invite the readers to ctitically analysing the identities of words with their perspectives. And thus, critical literacy will guide people towards a deeper appreciation of others meaning making in order to change the unjust worlds ((Fajardo, 2015). This means that the practice of positioning and putting others' opinion within own perception help to develop the enactment of critical literacy.

To foster to be critical in writing, however, still become a big challenge. Students tend to write from what they understand on the word and the world. In an effort to be literate critically in writing, Choo and Singh (2011) employ a media as an explicit approach in the learning instructions. The use of media had a great influence in students' writing through the critical thinking enactment on the ability of interpreting the content of media, analyze its social impact as well as explore the purpose, audience and ownership of the media. Beucher and Smith (2020) supported the notion that by providing the media texts in language instructions, students were invited to show their multiple perspectives and eventually they could arrive at their own conclusion. In further research, Janks (2013) considered the use of media texts to convey messages and to position people differently in relation to resources. Throughout the multimodal analysis toward the media texts, teachers are telling students to think critically the conscious positions. As every text is made from the author's intention, students are invited to realize it for their making meaning about the issues presented.

However, it is reported that putting critical literacy theory into practices is not as an easy served. Accordingly, frameworks to help in translating the critical literacy concept have been developed by a number of scholars. The frameworks facilitate not only on the practice of language skills but also a meaningful synthesis of the development of critical consciousness (Abednia A, 2015). Nevertheles, the whole activity presented in the frameworks of critical literacy are assigned in order to promote social change, as the character of the goal of the critical literacy performance (Vasquez et al, 2019; Sipitanos, 2021). Language teachers can attain to experience the critical literacy embedded in subject matter using the suited frameworks in the classroom for doing literacy work and it should look, feel, and sound different in different context (Vasquez, 2010; Luke, 2014; Comber, 2016). In accordance with this, the present study looked at how students' belief and attitudes of critical literacy enactment towards the information from online media affect their writing practices.

\section{Literature Review}

Critical Literacy is an approach in which the transformation produced from social issues analysis (Luke, 2012) through the process of figuring out the identity and power, human expression, as well as the cultural engagement (Luke \& Dooley, 2011). It is rooted by Freire (1970) in his theory of critical pedagogy model that the process of transformation exists when the students see the world not as a static reality, but how they come to a problem posing with a critical approach. Freire (1972) further argued that in the process of reading and writing, critical consciousness should be highlighted through the language learning. Consequently, reading the word is simultaneously about reading 
the world mediated through self-experiences and the language used (Freire \& Macedo, 1987). The product of critical reading could create the opportunity in unpacking the untrue words that may build new ways of understanding and reacting upon the world (Luke, 2014).

Another definition of critical literacy given by Vasquez et al (2019) that critical litearcy is an instruction model as a way of being and doing around the globe. This framing means that being literate critically does not mean to take a negative viewpoint, rather, it means to look at an issue in different perspectives through analyzing process in order to offer possible suggestion for change and improvement. There are a number of theory have shaped the critical literacy definition that have been developed in the notion for teaching and learning that is applicable to all levels and languages of instruction, regardless of whether students are proficient in the language or not. Thereupon, the combination of such theories have resulted in various orientations or framework to critical literacy in practice (Vasquez et al., 2019).

McLaughlin and DeVoogd (2004) explained that critical literacy helped instructors and students think critically and creatively through questioning rather than passively accept the information they encounter. The interaction with many information sources suggested in reading with critical edge. As a result, the readers might use their power to question that perspective and engage in reflection about whose voice might be missing, discounted, or silenced. The essential understanding from this notion reveals diverse principles on critical literacy; such as, focuses on issues of power and promotes reflection, transformation, and action; focuses on the problem and its complexity; creating an environment to promote a critical stance; examining multiple perspectives ended in juxtapositioning texts (McLaughlin \& DeVoogd, 2004). These various theoretical principles help shape a range of approaches to pedagogy. In other words, language learners may not take critical reading, rather they learn much in critical analysis from being actively involved in multiple information.

Bawden and Robinson (2009) stated that the individual's understanding of the information and the way the information presented are potentialy affected by the level of information anxiety. Studies have shown the impact of the online media information varied greatly influenced the knowledge learning affect for students. New technologies have further contribute to the changing of the ways in gaining the information. Today's information can be easily accesed through the online sources that significantly impacted the information search behaviour of the students (Kulkarni et al, 2012). However, when searching for such information on online media, one is faced with an avalanche an information which include a mixture of facts and hoaxes that are difficult to separate from one another (WHO, 2020). The many forms of online media are electronic sources used with internet, such as newspapers, blogs, journals, webpages, etc.

To write well requires not just developing and organizing ideas, but also converting these ideas into legible writing (Richards \& Renandya, 2002). Writing requires complicated abilities such as planning and organization, as well as lower level skills such as spelling, grammar, and word choice (Richards \& Renandya, 2002). Because of this intricacy, writing teachers must choose suitable instructional methods.

\section{Materials \& Methods}

The participants in this study were 12 students of Non- English Department who enrolled English for Specific Purpose (ESP) subject at a private university in East Java Province, Indonesia. The English course objective was to have students to be able use English both spoken and written in several learning activities, such as discussion, presentation, and demonstration. The teaching method was implemented in the realm of students centered learning methods. Therefore, students enrolled ESP subject after they have passed the basic English.

The research design employed a descriptive evaluative in qualitative design which the aim was to explain the real condition of the classroom where the critical literacy was administered. In this qualitative study, the researcher also held as the lecturer who implemented the critical literacy approach in the classroom who collected the data of the research through observation and interview. In doing the study, the researcher was assissted by two senior lectures who served as the observer and assisted to evaluate the process. 


\section{Research Procedures}

To seek the critical literacy enactment, the researcher, first let the students in pairs to choose an opinion texts from online media which were classified into controversial issues. The way in freeing students in choosing the desired topics in order to help them in drawing the prior information about the designated issues. The students were encouraged to do collaborative discussion before they developed the argument in writing practices. The process in the discussion aimed to bring them towards multiple viewpoints happened during their dialogues on topics. At this time, the questions related to the uncovered ideas of texts were marked to gain several information about the author's intention in delivering such information. This discussion stage intended to find out students' specific comprehension and experiences in understanding the author's message and other aspects related to their perception of the text. Ethical considerations were adhered to in this study; such as all data collected used for research purposes only. The student anonymity were assured when giving responses during classes and interview sessions. They were told their honest responses would help provide useful data on their critical literacy practices.

A sample of demonstration was given in the form of how the researcher presented point of views relating an issue. The principles of being critical on an information were demonstrated through analyzing and interpreting text from multiple perspectives. Juxtaposing texts and information from different context were also altered to show the readers stand point on an issue. The lecture presentation on topic was aimed to bring out the critical ways of thinking which also part of being literate critically.

While the discussion sections, the researcher conducted interview by considering the questions based on critical literacy framework, such as:

- Do you agree with the author's point of view on the issue?

- What does the author want us to think about the issue?

- Whose voices are missing, silenced, or discounted in the text?

- In what ways may alternate points of view be represented?

- How would that bring to your comprehension of the text from a critical perspectives?

- Would your point of view change as a result of what you have learned?

The data taken from the interview and audio recording from group discussion were connected to the results of student written product. The four dimension of critical literacy framework from Lewison et al. (2002) was used to determine the students' belief and attitudes towards the enactment of critical literacy during the writing practices. Those dimension are: (a) disrupting the commonplace, (b) considering the multiple viewpoints, (c) focusing on sociopolitical issues, (d) taking action and promoting social justice. After the discussion and interview completed, the students as individual were required to write an opinion essay about their thinking on the topic. The data from students writing and the document from the interview were analyzed to recognize students' belief and attitudes towards their critical literacy stances.

\section{Result}

The 12 transcripts resulting from students' group discussion, interview and the students writing product were used as the primary data for this study. Several students' belief and attitudes on critical literacy during writing activities are presented and this follow the discussion from the four dimensions model of critical literacy from Lewinson et al (2002). The results are shown as follow:

\subsection{Disrupting the commonplace}

In the first dimension of disrupting the commonplace, most of students perform their understanding of the topic that they bring about to write by considering different point of view of issue constructed from several sources and media. The ways how students gain multiple understanding about the topic indicate that they try to position themselves in divergent world problem. It means that they endeavor in the multiple views awareness through this dimension. Thus, their critical literacy is outlined from the practice to problematize, interrogate, and analyze the sources from different 
media as the gate to shape their identity. In other words, the execution of the questioning and interrogating the texts are obviously recognized as the critical enactment on literacy. The students' belief on perceiving multiple voices about the world has illustrated their attitudes through questioning and interrogating the common understanding.

A range of resources that students resort to, including web-sites, blogs, and social media in the form of articles, videos, advertisements, podcast, and its kind were intended to compare every voice of the world to help them in the new language construction. These instances of practices illustrate how the students critique their world by seeing the different worlds and eventually disrupting the common setting and understanding. These commonalities performance follow the characteristics of critical literacy skills through perceiving multiple point of view (Lewison et al., 2002), constructing and reconstructing the status quo (Luke, 2000; Shor,1987; Vasquez, 2000), and shaping the identity through problematizing and questioning the texts ( Gee, 2008). The account of critical literacy practices through questioning approach the media has also been conducted to came out multiple perspectives more actively (Morgan, 2009; Hayik, 2016).

\subsection{Considering the multiple viewpoints}

In this dimension, most of students engage in activities which tend to draw self- opposing of the perspectives. This can be seen through how students look at the missing voices that are not included in the text. The students discuss various argumentation by presenting the uncover voices. Most students in each group come up with the silenced parts that were prompted by the media. Through this ways, critical literacy is apparently enacted by students through opening their mind to consider different multiple views point that are also become the component of the issues. Therefore, due to the author has the intention in featuring of every text, students marginalized each side of text during the process of dialogue. In this case, students endevour the ability to be open- minded with multiple views and explicitly support opinions and reasons with evidances. This attitude enables students to consider propositions from different angels on different media.

Students' belief to identify voices that are heard and missing also proves the practice of the critical literacy. In this dimension, students are engaged with literacy activities which can open up their mind and heart towards others' perspectives from various sides. Within this process, students are invited to create the visibility of making differences by way of examining the dominant voices. In this case, the conclusion that students try to establish towards any texts appear in multifarious thought. As such, the critical reading which they conveyed in the group discussion help students to turn up into their critical writing. Subsequently, this is supported by Kaur and Sidhu (2014) that meaningful learning experiences can be horned to students by giving them critical thinking repertoires in various subject activities through critical reading and critical writing practices. Additionally, Gustine (2013) also terminated the benefit of critical engagement with texts through reading and writing in critical manner.

\subsection{Focusing on the socio-politics}

This third dimension highlights students in the practices that incorporate larger social system. This is apparent when the topic that students discussed was the catastropes of flood happened in their near setting. The critical discussion built by students on why the flood happened in that place related to a larger socio- political system. Most of the students in the discussion dispute the critical reasons on the cause of the flood. For instance, Wahyu, in his group said that the flood hit in his city as a result of the people's behaviour. He attributed to the people's habit of life on throwing the rubbish in the river. Two of students in the group supported Wahyu's opinion based on their experiences when they saw people conciously throw the garbage in the river. They continue further on discussing the river condition from other country where they consider that the people in the country are adhere to make the rivers are spotless. In this case, students challenge the sosiopolitical systems they found in their daily life through perception that most people in their country are not aware with their environment.

Another critical responses given by different group of students who share the involvement of the government. In this group, the political thought is also hold when the students view the responsible of the disaster in the country laid on the government. Fikri, one of the student said that the power from the government may also influence the larger sociopolitical system in the country. According to him, the strict of regulation given by the authority where the people live, 
will affect on the people's mental state. This responses indicate the power identity within sociopolitical issues as revealed in his writing below:

Fikri menulis "pemerintah seharusnya juga ikut menjadi bagian atas perilaku tidak disiplin penduduknya. Karena jika dibiarkan kebiasaan buruk tersebut juga akan berakibat merusak lingkungan."

Fikri writes "the government should also be part of the undisciplined behavior of the population. Because if the regulation left unchecked, the people's bad habits will also damage the environment."

The above propositions indicates that students also relate the environment, social behaviour, and socio political in presenting their perspectives on an issue. Students evaluate how the people's behaviour towards the environment also affect on the rules given by the authority. These manner activate students' attainment of the belief and attitude through the association between social and political factor. It is apparant when students view the issue of environment conservation which is also influenced by both social attitudes and by political policies.

\subsection{Taking action}

In this last dimension, students are required to represent their ideas in the essay writing form into different form of writing. They demonstrate their ideas in different writing project in order to be accessible by other reader. This dimension can be perceived when students think and plan to reconstruct the ideas in various texts. The project from some of the students explore how they instill the critical thinking while developing the published texts. For example, Anjar redesign his essay in the form of poster where the message is written in multimodal text presenting the wording information with coloring pictures that has the aim to attract his reader. His opinion on the way how he is directed to shift the ideas into different text revealed in a positive answer. The evident is clearly seen from the result of the interview below.

The most challenging part in the process of writing is when I have to think to put my ideas from essay writing into different writing format. At first, I thought that it would difficult for me to share my ideas to reader. But, then I find it easy to read when I rewrite and reconstruct my essay into poster. By doing so, I can put out the message to my friends through my social media. In addition, I can share my creativity in designing the poster using combinations of words, pictures, and color.

From Anjar's response, it is obvious that he take the new position from essay writer to poster creator. Notwithstanding, He writes in different form of writing, the ideas and messages presented in that both writing forms are the same. His belief on taking part of social transformation is contemplated through the process of designing and redesigning texts.

\section{Discussion}

The belief and attitude shown by the students in the comprehension of critical enactment during writing practices towards issues taken from online media suggest the positive of critical literacy convention in the classroom. The adoption of critical approach in the teaching of writing, have led students to shape their belief and attitude into several conception of critical literacy practices.

\subsection{The concept of acknowledging background knowledge}

Critical engagement with the word and the world that the teacher have brought in the class through juxtaposing the issues related to students daily life has already been a vast for starting point on critical literacy understanding. The scaffolding process that the teacher has coveyed on related issues activated students' attitude in using different information taken from various media. Such practices have invited students to engage with the topic using their prior knowledge in order to understand what they knew about the issue and how they have affected by it in the working field of group discussion.Teachers'modeling of helping students by generating ideas on understanding the text's 
purpose through delivering different types of questions has challenged or promoted the production of critical literacy (Abednia, 2015). This activity has effective in bringing the outside world into the classroom practices. As it has been explored by Land et al, 2018 that teachers and students may use talk to think about problems of social issues together for activating learning. In addition, the collaborative learning within group discussion has shared an important critical approach that highlighted a more recursive individual discourses. Hence, Zhang, 2015 suggested that critical literacy tends to play if a more on discourses by authors are explored and involved broadly on relevant background information.

\subsection{The concept of Exploring students' power in making inferences}

The work on how students experience in making meaning related with the topic has shown in line with Kaur's, (2014) findings that when students read various related texts and make an effort to understand the context, they have attempted to understand the author's message by recognising disparate opinions from variant sources. This practice has engage the students to make inferences during the reading process. Students' attitudes to confront with divergent information has avoided them to come up opinion without presenting the facts and evidences. As such, this strategy is good in reading and writing activities to have students connect their comprehension and draw consclusion.

\subsection{The concept of practising with critical literacy framework}

The students' performances in enacting the principles of critical literacy through the four dimension models from Lewinson et al (2002) have highlighted with several previous studies on similar beliefs and attitudes. In disrupting the commonplace, students deal with the critical inquiry turns into the practices in questioning and problematizing the issue constructed by the media. It is consistent with Nam's (2020) finding that critical engagement with texts may promote students disrupt the commonplace in critical literacy execution. In considering the multiple viewpoints, the students' different voices on the missing ideas presented in text has encouraged them to think about the silent words. This finding confirms with Gustine (2013) that the experience to be critical or creative thinking on different perspectives, help them to understand people's feelings and experiences. While the topics and related issues on socio politics has supported students to the opportunity to recognize and cope with a wider social system that eventually at the end the students are able more actively engage and take action with critical socio practices (Lewinson et al, 2002).

\section{Conclusion}

This study has set out to understand how students responded to the exploration of critical literacy theories and practices. Their beliefs and attitudes towards critical literacy comprehension from the issues on online media, suggest the realization of critical literacy execution. As a result, the critical approach need to be acknowledged to help students stay away from the involvement of unfaithful information. On the other hand, this critical ways of thinking on literacy allow the problem solving as students incorporate with thw word and their world.

\section{References}

Abednia A. (2015). Practicing critical literacy in second language reading.

Fajardo, M. F. (2015). A review of critical literacy beliefs and practices of English language learners and teachers.

Janks, H. (2013). Critical literacy in teaching and research1. Education Inquiry, 4(2), 225-242. https://doi.org/10.3402/edui.v4i2.22071

Kamler, B. (2017). Critical literacy: what's writing got to do with it? (Vol. 50, Issue 2).

Luke, A. (2012). Critical Literacy: Foundational Notes. Theory into Practice, 51(1), 4-11. https://doi.org/10.1080/00405841.2012.636324. 
Luke, A. (2014). Defining critical literacy.

Luke, A., \& Dooley, K. (2011). Critical Literacy And Second Language Learning (Handbook of Research in Second Language Teaching and Learning (ed.); In Hinkel, E (Ed.)). Routledge.

McLaughlin, M., \& DeVoogd, G. (2004). Critical Literacy as Comprehension: Expanding Reader Response. Journal of Adolescent \& Adult Literacy, 48(1), 52-62. https://doi.org/10.1598/jaal.48.1.5.

Nam, J. (2020). Critical literacy practices in the ESL reading classroom. International Journal of Critical Pedagogy.

Sipitanos, K. (2021). Evaluating Students' Final Text Production in Polyphonic Critical Literacy Practices: Combining Appraisal Theory with Qualitative Data Sources. International Journal of Education and Literacy Studies, 9(1), 113. https://doi.org/10.7575/aiac.ijels.v.9n.1p.113.

Vasquez V, Janks H, \& Comber B. (2019). Critical literacy as a way of being and doing. Language Arts, 96(5). 